\title{
Marlena Drapalska-Grochowicz
}

Uniwersytet Śląski, Katowice

mdrapalska@gmail.com

ORCID: https://orcid.org/0000-0002-8602-2918

\section{Kilka uwag na tle statusu prawnego rodzin $z$ wyboru*}

http://dx.doi.org/10.12775/SIT.2018.027

Powszechnie rodzina jest rozumiana jako wspólnota o zastanej, tradycyjnie ukształtowanej formie. W tym kontekście związki jednopłciowe bywają postrzegane jako całkowita antyteza życia rodzinnego - kategoria graniczna, która oddziela świat „normalnych” i „nienormalnych” ${ }^{1}$. Bycie gejem lub lesbijką jest równoznaczne $z$ wykluczeniem $z$ form życia rodzinnego i $z$ bezdzietnością. Takie założenie wiąże się ze ścisłym powiązaniem trzech elementów - heteroseksualności, małżeństwa i rodzicielstwa ${ }^{2}$. Takiemu połączeniu sprzyjają również współczesne mechanizmy prawne i społeczne, objawiające się w postaci obyczajów czy zasad prawodawczych, które mają za zadanie kontrolować sposoby wyrażania seksualności człowieka tak, aby uzyskała ona pożądany kształt, tj. heteroseksualnego małżeństwa i następnie rodzicielstwa. Powyższe wynika

* Publikacja artykułu została sfinansowana ze środków Narodowego Centrum Nauki na podstawie decyzji numer UMO-2018/29/N/HS5/00905.

${ }^{1}$ T. Szlendak, Socjologia rodziny. Ewolucja, historia, zróżnicowanie, Warszawa 2012, s. 486-487.

2 D. Majka-Rostek, Macierzyństwo lesbijek - wybrane konteksty społeczne, „Studia Socjologiczne” 2014, nr 4, s. 61. 
z kulturowego powiązania pojęć seksualności oraz prokreacji jako podstawowych wyznaczników pożycia ${ }^{3}$.

Dyskurs na temat praw osób LGBT jest w pewien sposób „nieludzki" - o osobach nieheteronormatywnych pisze się jako o problemie, zapominając o tym, że ów „problem” ma wymiar ludzki i dotyczy realnej sytuacji tych osób i ich bliskich ${ }^{4}$. Przy określaniu relacji tych osób unika się określeń „rodzinnych” - są one przedstawiane w oderwaniu od rodziny lub ewentualnie jako pretendujące do miana rodziny alternatywnej ${ }^{5}$. Jednak w świetle współczesnej socjologii związki jednopłciowe są uznawane za formy życia rodzinnego ${ }^{6}$. Ważnym elementem życia rodzinnego osób nieheteronormatywnych jest ich prawo do wychowania własnych dzieci i założenia rodziny. Pomimo nieobecności tego tematu w dyskursie rodzicielstwo osób LGBT jest faktem społecznym. Status prawny dzieci wychowywanych przez homoseksualnych rodziców jest immanentnie związany ze statusem prawnym związku ich rodziców. Jeżeli związek ten nie ma charakteru zinstytucjonalizowanego, również sytuacja (co najmniej prawna) dzieci w nim wychowywanych ulega pogorszeniu. Związki jednopłciowe i tworzone przez nie rodziny budzą społeczny niepokój w Polsce. Jak pokazują badania opinii społecznej, rodzicielstwo osób LGBT jest jedną z najbardziej wrażliwych i najmniej akceptowanych społecznie kwestii ${ }^{7}$. Obawy te opierają się na założeniu, iż umożliwienie związkom jednopłciowym adopcji stanowi zagrożenie dla dobra dziecka. Należy zatem rozważyć, czy w kontekście rodzicielstwa osób nieheteronormatyw-

${ }^{3}$ J. Bancroft, Seksualność człowieka, red. wydania polskiego Z. Lew-Starowicz, A. Robach, Toronto 2009, s. 19-20.

${ }^{4}$ J. Mizielińska, A. Stasińska, Prywatne jest polityczne: strategie emancypacyjne rodzin $z$ wyboru $w$ Polsce. Studium wybranych przypadków, „Studia Socjologiczne” 2014, nr 4, s. 112.

${ }^{5}$ J. Mizielińska, A. Stasińska, Prywatne jest polityczne, s. 111.

${ }^{6} \mathrm{~K}$. Slany, Alternatywne formy życia małżeńsko-rodzinnego $w$ ponowoczesnym świecie, Kraków 2002, s. 17-18.

7 CBOS, Stosunek do praw gejów i lesbijek oraz zwiazków partnerskich, Warszawa 2013, s. 4. Badania przeprowadzone przez CBOS od 2001 r. do 2013 r. pokazują, że najmniej akceptowalnym postulatem środowisk LGBT w Polsce jest kwestia adopcji (84-90\% respondentów wypowiedziało się przeciw). 
nych klauzulę „dobro dziecka” będziemy odczytywać inaczej niż w przypadku rodziców heteroseksualnych oraz czy można mówić o zagrożeniu „dobra dziecka” w przypadku wychowywania przez parę jednopłciową. Ponadto w związku $\mathrm{z}$ przemianami form życia rodzinnego nasuwa się pytanie o potrzebę redefinicji tradycyjnych pojęć, takich jak „rodzina”, „małżeństwo” czy „rodzicielstwo”. Czy należy dążyć do zmiany zastanych pojęć innymi, czy raczej wypełniać je nowym znaczeniem?

Niniejszy artykuł stanowi spojrzenie na zagadnienie rodzin $z$ wyboru $z$ perspektywy prawnika. Prawnicy powinni być bacznymi obserwatorami rozwoju innych nauk, w szczególności socjologii, która dostarcza niezbędnej i aktualnej wiedzy na temat funkcjonowania społeczeństwa popartej badaniami empirycznymi. To właśnie dzięki pracom socjologów i psychologów możemy poznać realny wymiar życia rodzin $z$ wyboru. Poprzez konkretne rozwiązania prawne oraz wolę ich prawidłowego odczytania prawo może jedynie (albo i aż) ułatwić życie rodzin $z$ wyboru. W obecnym stanie prawnym rodziny z wyboru zdają się niewidoczne dla polskiego ustawodawcy. Należy podkreślić, że rozwiązanie problemów rodzin $z$ wyboru nie mieści się jedynie w prawie. To zmiana wrażliwości społecznej, popularyzacja wiedzy na temat ich funkcjonowania jest zasadniczym „pierwszym krokiem" ku polepszeniu bytu rodzin $\mathrm{z}$ wyboru.

\section{Rodziny z wyboru*}

Zgodnie $z$ danymi zawartymi w raporcie „Rodziny $z$ wybory. Życie rodzinne osób nieheteronormatywnych w Polsce." w Polsce mieszka ponad dwa miliony osób LGBT, $\mathrm{z}$ czego około połowa żyje w związ-

* Pod pojęciem rodziny z wyboru należy rozumieć także takie wspólnoty nienormatywne jak konkubinaty czy rodziny wychowujące faktycznie obce dziecko (tzw. wychowaniec). W artykule skupiono się jednak na sytuacji prawnej rodzin jednopłciowych ze względu na specyfikę problemów praktycznych, z jakimi stykają się w codziennym życiu, co dodatkowo komplikuje niska tolerancja społeczna. 
kach intymnych, a część $z$ nich wychowuje dzieci tworząc tzw. rodziny $z$ wyboru ${ }^{9}$.

W pierwszej kolejności należy zatem odpowiedzieć na pytanie, czym w ogóle są rodziny $z$ wyboru. Termin rodziny $z$ wyboru został po raz pierwszy użyty przez Kath Weston w książce Families We Choose: Gays, Lesbians and Kinship, w której opisano popularyzację pojęcia „rodzina” wśród osób homoseksualnych już w połowie lat 80. XX w. Dostrzeżono przełamanie znaczenia więzów biologicznych, które w przypadku osób LGBT okazywały się często kruche, oparte na braku akceptacji i zrozumienia, natomiast relacje faktyczne zastąpiły i wypełniły funkcje dotychczas przypisywane jedynie rodzinie biologicznej - poczucie solidarności, odpowiedzialności i opieki ${ }^{10}$. Rodziny zakładane przez pary jednopłciowe można nazwać rodzinami $z$ wyboru, ponieważ osoby te chcą $z$ wyboru być rodziną i tak się nazywać. Pomimo braku społecznej akceptacji wzorców takich rodzin funkcjonują one „Z wyboru”. Partnerzy w związkach jednopłciowych, wychowując dzieci, starają się powielać wzorce i „tradycyjny” podział ról, opierający się na doświadczeniach własnego życia rodzinnego ${ }^{11}$. Istotnym problemem życia rodzinnego osób LGBT jest ich mniejszościowy status i niska tolerancja spo-

9 J. Mizielińska, M. Abramowicz, A. Stasińska, Rodziny z wyboru w Polsce. Życie rodzinne osób nieheteroseksualnych, Warszawa 2014, s. 11, http:// rodzinyzwyboru.pl/wp-content/uploads/2014/10/Raport_Rodziny-z-wyboruw-Polsce.-\%C5\%BBycie-rodzinne-os\%C3\%B3b-nieheteroseksualnych.pdf (data dostępu: 20.06.2018 r.). W raporcie wskazano, że „W większości światowych badań nad homoseksualizmem podaje się, że w każdej populacji żyje około 5\% osób homoseksualnych, co by oznaczało, że gejów i lesbijek w Polsce jest ok. 2 milionów". Brak jest statystyk odnośnie do osób biseksualnych i transpłciowych żyjących w związkach z osobą tej samej płci, dlatego umownie w niniejszym raporcie podano szacunkową liczbę „ponad 2 miliony”.

10 J. Mizielińska, A. Stasińska, Rodzina z wyboru, hasło w: Encyklopedia gender. Pteć kulturowa, red. K. Nadana, G. Latos, IBL PAN (w przygotowaniu), s. 1, http://rodzinyzwyboru.pl/wp-content/uploads/2013/07/Joanna-Mizielińska_Agata-Stasińska_hasło-Rodziny-z-wyboru_Encyklopedia-Gender.-Płeć-kulturowa_red.-K.-Nadana-G.-Latos_IBL-PAN-pdf.pdf (dostęp: 20.07.2018 r.).

${ }^{11}$ M. Ukleja Rodziny z wyboru. Homoseksualny związek jako współczesna alternatywa rodziny - Analiza zjawiska, „Acta Universitatis Lodziensis. Folia Sociologica” 2014, nr 51, s. 126. 
łeczna. Pary jednopłciowe wychowujące dzieci muszą zmierzyć się z brakiem kulturowych skryptów stanowiących wzorce kreowania relacji rodzinnych. Muszą wypracować własne wzorce i strategie funkcjonowania w heteronormatywnym środowisku społeczno-kulturowym, czerpiąc $z$ własnych doświadczeń życia rodzinnego ${ }^{12}$.

W literaturze prawniczej można jednak spotkać głosy kwestionujące możliwość tworzenia form rodzinnych przez związki inne niż heteroseksualne. Zdaniem Tadeusza Smyczyńskiego formy pożycia rodzinnego nie mogą być dowolnie poszerzane i wykorzystywane do partykularnych celów. Stosunki rodzinnoprawne, będąc stabilizatorem relacji rodzinnych, dedykowane są małżonkom, a w szczególności ich relacji $z$ dziećmi, ustawodawca w związku $z$ tym nie może tworzyć modeli życia rodzinnego „do wyboru” ${ }^{13}$. Autor wskazuje, że fundamentem rodziny jest para składająca się z mężczyzny i kobiety. Osoby pozostające we wspólnym pożyciu mogą tworzyć grupę społeczną, która będzie naśladować życie rodzinne, jednak ze względu na nieusuwalną przeszkodę naturalną nie jest ono życiem rodzinnym. Pojęcie rodziny należy wiązać $z$ kręgiem osób pochodzących od siebie albo od wspólnego przodka, a pary jednopłciowe nie staną się grupą rodzinną, nawet jeżeli wychowują wspólnie dziecko ${ }^{14}$. Pożycie osób tej samej płci nie może być w ogóle rozpatrywane w kategoriach prawa rodzinnego, gdyż „upodobania seksualne można mieć różne, ale nie wolno żądać od społeczeństwa pomocy w ich zaspakajaniu"15. W podobnym duchu wypowiada się Małgorzata Łączkowska, która charakteryzuje rodzinę przez pryzmat funkcji i celów, jakie tradycyjnie powinna spełniać, tj. prokreacji i wychowania przyszłych pokoleń. Tym samym wskazuje, iż stosunki pomiędzy osobami tej samej płci nie mogą zostać objęte kategoriami prawa rodzinnego, gdyż nie realizują one żadnej z wyżej wymienionych funkcji,

12 D. Majka-Rostek, Lesbijki, geje i ich dzieci - różnorodność form rodzinnych, „InterAlia” 2013, nr 8, s. 13-14.

${ }^{13}$ T. Smyczyński, Małżeństwo - konkubinat - związek partnerski, w: Związki partnerskie - debata na temat projektowanych zmian prawnych, red. M. Andrzejewski, Torun 2013, s. 73-75.

${ }^{14}$ Idem, Prawo rodzinne i opiekuńcze. System prawa prywatnego, t. 11, red. T. Smyczyński, Warszawa 2014, s. 2-4.

${ }^{15}$ Idem, Małżeństwo-konkubinat-związek partnerski, s. 75. 
związek ten w opinii autorki jest oparty na realizacji „prywatnych potrzeb emocjonalnych i seksualnych" ${ }^{16}$. Trudno jednak zgodzić się z poglądem, który oparty jest na założeniu, że orientacja inna niż heteroseksualna jest wyłącznie składnikiem życia prywatnego i jako taka nie powinna znajdować się w zakresie zainteresowania ustawodawcy. Dlaczego zatem orientacja heteroseksualna, mimo iż niewątpliwie jest elementem życia intymnego, jest prawnie uznana?

Prawo nie jest „w stanie” regulować wszelkich możliwych sytuacji faktycznych występujących w rzeczywistości społecznej. Tutaj jednak istotną rolę odgrywa interpretacja prawa, która powinna być czyniona w oparciu o rzetelne przesłanki płynące z założeń nauk, które zajmują się badaniem faktycznego wymiaru funkcjonowania społeczeństwa. Ustawodawca oraz wspólnota interpretacyjna nie mogą pozostać obojętne na współczesne przemiany życia rodzinnego, stąd zastane i tradycyjne pojęcia powinny być wypełniane aktualnym, rzeczywistym znaczeniem, tak aby stanowiły jak najbardziej adekwatne narzędzie w kształtowaniu sytuacji prawnej określonych osób. Rodziny $z$ wyboru realnie funkcjonują w rzeczywistości społecznej, jednak w oczach ustawodawcy pozostają niewidzialne i na podstawie arbitralnych kryteriów pominięte jako nie wartościowe i patologiczne. Szereg empirycznych badań naukowych z zakresu socjologii i psychologii wskazuje na faktyczne funkcjonowanie tych rodzin oraz niczym nieuzasadnione utrudnienia w ich codziennym życiu ${ }^{17}$. Takie wartości jak rodzina, stabilizacja, współodpowiedzialność nie są tylko właściwością związków heteroseksualnych - jest

${ }_{16}$ M. Łączkowska, Związki osób tej samej ptci w świetle prawa polskiego, w: Prawo wobec wyznawań wspótczesności t. III, red. P. Wiliński, O. Krajniak, B. Guzik, Poznań 2006, s. 359-362.

${ }^{17} \mathrm{~W}$ szczególności należy zwrócić uwagę na takie pozycje jak: J. Mizielińska, A. Struzik, A. Król, Różnym gtosem. Rodziny z wyboru w Polsce, Warszawa 2017; J. Mizielińska, Odmienne czy zwyczajne? Rodziny z wyboru $w$ Polsce, Warszawa 2017; J. Mizielińska, A. Stasińska, There is nothing like a family: disocurses on families of choice in Poland, "Journal of Homosexuality” 2016; J. Mizielińska, M. Abramowicz, A. Stasińska, Raport Rodziny z wyboru w Polsce. Zycie rodzinne osób nieheteroseksualnych Warszawa 2014; J. Mizielińska, Between silencing and ignoracnce: Families of choice in Poland, "Dialogue and Universalism" 2010, nr 5-6. 
to nieuzasadniona generalizacja, poprzez którą marginalizuje się wartość życia rodzinnego osób LGBT. Jak wskazuje Joanna Mizielińska i Agata Stasińska, „Rodzina jest dla osób nieheteroseksualnych ogromnie ważna. Może stanowić źródło wsparcia lub wykluczenia, może ich określać lub też nie, niewątpliwie jednak stanowi bardzo istotny punkt odniesienia tworzonych przez nie relacji”"

Dotychczas przeprowadzane badania dotyczące życia rodzinnego osób LGBT odnosiły się głównie do społeczeństwa zachodniego, co utrudnia ich bezpośrednią implikację na grunt realiów polskich. W latach 2014-2016 przeprowadzono pierwsze w Polsce kompleksowe badania pt. „Rodziny z wyboru” ${ }^{19}$, dotyczące kwestii związanych $z$ codziennym życiem, problemami, potrzebami i oczekiwaniami osób nieheteroseksualnych żyjących w Polsce. Zgodnie z wynikami badań zdecydowana większość respondentów uważa, iż związki osób tej samej płci tworzą rodzinę - 97\% badanych wskazuje, iż partner/partnerka są jego rodziną. Respondenci spytani o motywy posiadania dzieci wskazywali na chęć pogłębienia związku i stworzenia pełnej rodziny. Analogiczne powody leżą u podstaw chęci posiadania dzieci przez pary heteroseksualne ${ }^{20}$. W społeczeństwie jednak rozumienie pojęcia rodziny jest odmienne - tylko 14\% Polaków uważa, iż związek jednopłciowy bez dzieci jest rodziną, natomiast 23\%, jeżeli w związku są wychowywane dzieci ${ }^{21}$.

Wymiar rodzicielski związków jednopłciowych może być realizowany w trzech różnych płaszczyznach, tj. dziecko wychowywane przez parę jednopłciową może pochodzić z poprzedniego związku heteroseksualnego jednej ze stron, dziecko może zostać zaadoptowane przez jednego $\mathrm{z}$ partnerów albo też urodzić się $\mathrm{w}$ związku osób tej samej płci (in vitro, surogacja). W tym zakresie również nastąpiła przemiana. O ile w latach 70 . w przestrzeni społecznej zaczęły być widoczne rodziny $z$ wyboru, o tyle dzieci w tych ro-

18 J. Mizielińska, A. Stasińska, Prywatne jest polityczne, s. 122.

19 http://rodzinyzwyboru.pl (dostęp: 20.07.2018 r.)

20 J. Mizielińska, M. Abramowicz, A. Stasińska, Rodziny z wyboru w Polsce. Życie rodzinne osób nieheteroseksualnych, Warszawa 2014, s. 113-139.

${ }^{21}$ CBOS, Stosunek do praw gejów i lesbijek oraz związków partnerskich, Warszawa 2013, s. 5-6. 
dzinach pochodziły $z$ wcześniejszych relacji heteroseksualnych. Współcześnie jednak coraz powszechniejsze jest zjawisko rodzin z wyboru, w których macierzyństwo jest świadomie planowane i od początku realizowane jako nieheteronormatywne ${ }^{22}$. Jak wskazują badania, 92\% dzieci żyjących w rodzinach z wyboru urodziło się w poprzednim związku heteroseksualnym rodzica, natomiast 8\% w związku osób tej samej płci.

Niedookreślona prawnie pozostaje rola tzw. rodzica społecznego, czyli tego $z$ partnerów, który bierze udział w wychowaniu dziecka mimo braku biologicznych $z$ nim więzi. Jak wskazują badania, angażuje się on w równym stopniu w opiekę i wydatki na dziecko. Większość obowiązków związanych z opieką nad dziećmi jest wykonywana wspólnie ( $\mathrm{u}^{2} / 3$ badanych) ${ }^{23}$. Kodeks rodzinny i opiekuńczy nie dopuszcza jednak przysposobienia dziecka przez związki jednopłciowe. Także w przypadku dziecka biologicznego partnera/ /partnerki tzw. rodzic społeczny nie ma legalnej możliwości nabycia praw rodzicielskich. Zasadniczo w strukturze rodzinnej można wyróżnić trzy rodzaje powiązań: biologiczne, prawne i społeczne. W „rodzinach tradycyjnych” najczęściej występują one razem, natomiast $\mathrm{w}$ rodzinach $\mathrm{z}$ wyboru następuje ich „rozbicie”. Pozycja „rodzica społecznego” jest ograniczona jedynie do elementów społecznych. Ponadto ich sytuacji nie ułatwia tzw. kultura macierzyństwa, która zakłada prymat więzi biologicznej, a także przekonanie o „monomaternalizmie”, czyli o tym, że dziecko może mieć tylko jedną, prawdziwą matkę/ojca ${ }^{24}$.

Kontrowersje wokół zagadnienia rodzicielstwa osób homoseksualnych koncentrują się na trzech zasadniczych obawach:

- niepokoju o kształt i charakter orientacji seksualnej dziecka oraz o podejmowanie przez nie zachowań niezgodnych ze wzorcami płci,

${ }^{22}$ D. Majka-Rostek, Macierzyństwo lesbijek - wybrane konteksty społeczne, s. 73.

${ }^{23}$ J. Mizielińska, M. Abramowicz, A. Stasińska, Rodziny z wyboru w Polsce. Życie rodzinne osób nieheteroseksualnych.

${ }^{24}$ D. Majka-Rostek, Macierzyństwo lesbijek - wybrane konteksty społeczne, s. 71 . 
- obawie przed utrudnieniami i wykluczeniem w relacjach rówieśniczych ze względu na podwyższone ryzyko stygmatyzacji,

- obawie o wystąpienie trudności emocjonalnych w budowaniu własnych relacji miłosnych.

Rozwój dzieci wychowywanych przez pary jednopłciowe jest najlepiej przebadanym obszarem rodzicielstwa par homoseksualnych. Przemysław Tomalski, dokonawszy szczegółowej analizy badań odnoszących się do trzech wskazanych obszarów zagrożeń, wskazuje, iż dzieci wychowywane przez lesbijki i gejów nie dotykają trudności w przystosowaniu społecznym i rozwoju. Ponadto orientacja seksualna rodzica nie ma bezpośredniego przełożenia na orientację seksualną dziecka oraz podejmowane przez nie role płciowe. Rozwój dzieci osób homoseksualnych przebiega w zasadzie tak samo, jak dzieci wychowywanych przez osoby heteroseksualne. Należy zaznaczyć jednak, iż dzieci gejów i lesbijek, ze względu na niską tolerancję społeczeństwa wobec związków jednopłciowych, są narażone na częstsze sytuacje złego traktowania ${ }^{25}$. Jak wskazują badania Amerykańskiego Stowarzyszenia Psychologicznego, dzieci wychowywane przez homoseksualnych rodziców charakteryzują się tym samym poziomem rozwoju emocjonalno-społecznego i seksualnego, co dzieci wychowywane przez rodziców heteroseksualnych. Ponadto optymalny rozwój dziecka jest zależny nie od orientacji seksualnej rodzica, lecz od stabilności i siły więzi łączącej rodzica i dziecko, a także samych rodziców ${ }^{26}$. Należy podkreślić, iż w szczególności ze względu na dobro dzieci wychowywanych w rodzinach zakładanych przez pary jednopłciowe ich status prawny powinien zostać uregulowany. Dzięki temu wspólnota ta nabędzie normatywnie sankcjonowane cechy, takie jak stabilność i trwałość, co sprzyja odpowiedniej atmosferze wychowania dziecka, bezpieczeństwu prawnemu i zabezpieczeniu jego sytuacji na wypadek rozstania się osób je wychowujących lub śmierci jednej z nich.

${ }^{25}$ P. Tomalski, Nietypowe rodziny. O parach lesbijek i gejów oraz ich dzieciach $z$ perspektywy teorii przywiazania, Warszawa 2007, s. 65-76.

${ }^{26}$ American Psychological Association Policy, Sexual Orientation, Parents and Children, http://www.apa.org/about/policy/parenting.aspx (dostęp: 18.05.2018 r.). 
Warto także zwrócić uwagę na problemy, z którymi stykają się osoby żyjące w związkach jednopłciowych i posiadające dzieci z poprzedniego heteroseksualnego związku. Są one narażone na próby ograniczenia lub pozbawienia władzy rodzicielskiej z powodu swojej orientacji seksualnej oraz na utrudnianie kontaktów z dzieckiem. Ponadto małżonkowie heteroseksualni uznają swój prymat w decydowaniu o sprawach dziecka, uważając się a priori za lepszego $z$ rodziców ${ }^{27}$. Decydując się na rodzicielstwo, pary jednopłciowe stają przed wieloma wyzwaniami codzienności. Jeżeli postanawiają mieć biologiczne potomstwo, muszą wybrać której z partnerek/którego z partnerów będzie to dziecko. Ponadto muszą ustalić rodzinne nazewnictwo. W przypadku gdy znany jest dawca nasienia, para musi zdecydować, czy ma on być w przyszłości częścią rodziny, a jeżeli tak, to w jaki sposób ma w niej funkcjonować. Można zatem powiedzieć, że rodzicielstwo osób nieheteronormatywnych nie ma charakteru „pojedynczego”, ale jego zakres obejmują różne typy relacji, w skład których mogą wchodzić np. dawcy nasienia czy zastępcze matki.

Ponadto istotnym problemem praktycznym jest kwestia statusu cywilnego dzieci wychowywanych w związkach jednopłciowych. Jako przykład może posłużyć sprawa, w której para kobiet zamieszkałych w Wielkiej Brytanii złożyła w USC w Polsce wniosek o sporządzenie w polskich księgach stanu cywilnego zagranicznego aktu urodzenia ich córki urodzonej w Londynie. Do wniosku załączono uwierzytelnioną kopię wpisu do ewidencji, z którego wynika, że jedna $z$ nich jest matką, a druga jest wpisana jako rodzic. Kierownik USC odmówił transkrypcji zagranicznego aktu stanu cywilnego na podstawie ówczesnego art. 73 ust. 1 i art. 7 Ustawy z 4 lutego 2011 r. - Prawo prywatne międzynarodowe ${ }^{28}$. Zasadniczym zagadnieniem w niniejszej sprawie była zatem transkrypcja aktu stanu cywilnego sporządzonego za granicą, w którym jako rodzice zostały

${ }^{27}$ M. Zima, Prawo osób homoseksualnych do życia rodzinnego - prawo do wychowania własnych dzieci, w: Tęczowe rodziny $w$ Polsce. Prawo a rodziny lesbijskie i gejowskie, red. M. Zima, Warszawa 2010, s. 35-37.

${ }^{28}$ Art. 7 Ustawy z 4.02.2011 r. - Prawo prywatne międzynarodowe: „Prawa obcego nie stosuje się, jeżeli jego stosowanie miałoby skutki sprzeczne $z$ podstawowymi zasadami porządku prawnego Rzeczypospolitej Polskiej”. 
wskazane osoby tej samej płci. Wpisując do polskiej księgi urodzeń tak sporządzony za granicą akt urodzenia, kierownik urzędu stanu cywilnego musiałby jedynie przenieść treść aktu zagranicznego do polskiej księgi urodzeń. W konsekwencji do aktu urodzenia dziecka wpisane zostałyby dwie kobiety, przy czym jedna $z$ nich $w$ rubryce „ojciec”. Powołując się na słownikowe znaczenie tych pojęć, Naczelny Sąd Administracyjny wskazał, że „nie chodzi przy tym wyłącznie o wzory druków, gdyż nawet gdyby druki miały rubrykę "rodzic", to przez "rodziców" rozumie się w Polsce w sposób jednoznaczny ojca i matkę, zaś w aktualnym stanie prawnym niedopuszczalne jest wpisanie do aktu stanu cywilnego dwóch kobiet, jako ojca i matki lub jako rodziców. Zdaniem zaś Naczelnego Sądu Administracyjnego, nawet, gdyby nazwa rubryki brzmiała "rodzic", to słowo rodzic w dawnej polszczyźnie występowało zawsze w znaczeniu "ojciec", istniał również żeński odpowiednik rodzica, czyli "matka". Semantyczne znaczenie słowa "rodzice" to: "ojciec i matka w stosunku do swojego dziecka", zaś "rodzic" oznacza jedno z rodziców lub ojca"29. Ponadto sądy administracyjne stoją na stanowisku, iż transkrypcja ma charakter rejestracji wtórnej, która powoduje powstanie polskiego aktu urodzenia dziecka. Domniemanie prawidłowości zagranicznego aktu stanu cywilnego wskazuje, że rodzicami dziecka są osoby tej samej płci i kwestia ta nie powinna podlegać ocenie przez polskiego urzędnika, ponieważ jest to fakt już ukształtowany pod rządami prawa właściwego i odmowa transkrypcji tego nie zmieni, osoby te bowiem tak czy inaczej będą rodzicami dzieci, zatem powinni zostać wpisani w obowiązujące rubryki w polskich aktach stanu cywilnego jako „matka” i „ojciec”, (chociażby w formie przypisku) gdyż stanowiłoby to rozwiązanie bliższe rzeczywistości. Ponadto, akt urodzenia dziecka sporządzony za granicą stanowi wyłączny dowód tego, co zostało w nich stwierdzone, tj. tego, że dziecko urodziło się określonego dnia, a co najmniej jeden $z$ rodziców jest Polakiem.

W opisywanych sprawach organy orzekające zdają się uwypuklać te kwestie, które mają drugorzędne znaczenie dla meritum sprawy. Wysuwając na pierwszy plan te wciąż dość kontrowersyjne wątki

${ }^{29}$ Wyrok NSA z dnia 17 grudnia 2014 r., III OSK 1298/13, http://orzeczenia.nsa.gov.pl/doc/ADA943DFA1 (dostęp: 15.07.2018 r.). 
w polskim dyskursie sądy tworzą iluzję zagrożenia polskiego porządku prawnego, jakoby transkrypcja miała „wprowadzać tylnymi drzwiami” związki jednopłciowe i ich rodzicielstwo do polskiego porządku prawnego. Organy kwestionują bowiem możliwość istnienia rodzicielstwa osób tej samej płci - z powodu biologicznej niemożności, z powodu „nienaruszalnego znaczenia” i w końcu mnożąc szereg iluzorycznych przeszkód formalnych. Wysunięcie na pierwszy plan kwestii rodzicielstwa związków jednopłciowych, które nie są instytucjonalizowane $\mathrm{w}$ prawie polskim stanowi w tym przypadku swoiste utrudnienie w uzyskaniu uprawnień, które małoletniemu będącemu obywatelem polskim zwyczajnie się „należą”. Co istotne, odmowa dokonania transkrypcji zagranicznego aktu stanu cywilnego powoduje ograniczenie podstawowych praw związanych $\mathrm{z}$ posiadaniem obywatelstwa polskiego tj. niemożność nadania numeru PESEL, uzyskania polskiego dokumentu tożsamości, co następnie może rodzić ograniczenie w dostępie do systemu ochrony zdrowia czy oświaty. Argumentacja w analogicznych sprawach jest oparta na zastanej interpretacji pojęcia „rodziny”, „małżeństwa”, a następnie poprzez sięganie bez uzasadnienia po tak wrażliwe narzędzie jak klauzula porządku publicznego ${ }^{30} \mathrm{z}$ powołaniem na art. 18 Konstytucji RP oraz podstawowe zasady prawa rodzinnego ${ }^{31}$.

${ }^{30}$ Naruszeniem porządku publicznego nie jest sama sprzeczność obcych norm merytorycznych z porządkiem publicznym fori, lecz wyłącznie ich potencjalnego oddziaływania (tj. skutki), które może uzasadniać wyłączenie zastosowania. Przede wszystkim odmowa transkrypcji zagranicznych aktów stanu cywilnego potwierdzających zawarcie związku jednopłciowego czy rodzicielstwo pary jednopłciowej nie spowoduje ich „wprowadzenia” do polskiego porządku prawnego, a jedynie przyczyni się do ułatwienia kwestii dowodowych w różnego rodzaju postępowaniach, uznania i zarejestrowania tego stanu zgodnie $z$ zasadą jedności i niepodzielności stanu cywilnego. Przy tym wskazać również trzeba, że zastosowanie klauzuli porządku publicznego dotyczy wyłącznie sytuacji stosowania prawa obcego, natomiast art. 107 PrASC jest regulacją polską (tak: M.A. Zachariasiewicz, Nowa ustawa o prawie prywatnym międzynarodowym a małżeństwa i związki osób tej samej ptci, „Problemy Prawa Prywatnego Międzynarodowego" 2012, t. 11, s. 95 s. 99-100; M. Pilch, Związki quasi-matżeńskie $w$ polskim prawie prywatnym międzynarodowym (po nowelizacji k.k.), „Państwo i Prawo” 2011, nr 2, s. 93).

${ }^{31}$ Tak przykładowo: wyrok WSA w Krakowie $z$ dnia 10 maja 2016 r., III SA/ /Kr 1400/15, http://orzeczenia.nsa.gov.pl/doc/431B8D990D; wyrok WSA 
Należy podkreślić, że sama transkrypcja zagranicznego aktu jako czynność reprodukcyjna nie zmieni w polskim porządku prawnym nic szczególnego, a jej skutki będą z nim zgodne (będą sprzyjały pewności obrotu i jego przejrzystości). Transkrypcja aktu urodzenia dziecka, którego rodzicami są osoby tej samej płci skutkowałaby bowiem tylko jednym: małoletni uzyskałby rzeczywistą możliwość realizacji uprawnień przysługujących mu jako obywatelowi polskiemu. Transkrypcja nie kreuje nowej rzeczywistości, tzn. samo przepisanie aktu nie powoduje „powstania” rodzicielstwa jednopłciowego czy małżeństwa jednopłciowego w prawie polskim, te stosunki są bowiem uregulowane pod rządami prawa dla nich właściwego.

Prawo do ochrony życia rodzinnego zgodnie $\mathrm{z}$ dominującym ujęciem obejmuje swoim zakresem małżeństwo, pokrewieństwo i powinowactwo, natomiast nie obejmuje innych stosunków, tj. konkubinatów hetero- i homoseksualnych, gdyż nie są one uznawane za formy życia rodzinnego. Stwierdzenie to zasadza się na rozumieniu rodziny jako składającej się $z$ małżonków oraz dzieci pochodzących $z$ tego związku ${ }^{32}$. Rodzicielstwo natomiast może być oparte na więzi zarówno biologicznej, jak i prawnej. Podlega ono ochronie niezależnie od tego, czy dotyczy małżeństwa czy osoby samotnie wychowującej dziecko ${ }^{33}$. W związku z tym konstytucyjną ochroną i opieką objęte jest zarówno rodzicielstwo osób homoseksu-

w Gliwicach z dnia 6 kwietnia 2016 r., II SA/Gl 1157/15, http://orzeczenia.nsa.gov.pl/doc/2534285900; wyrok WSA w Łodzi z 14 lutego 2013 r., III SA/Łd 1100/12, http://orzeczenia.nsa.gov.pl/doc/9851327A71 (dostęp: 11.07.2018 r.). Pozytywną „prognozą orzeczniczą” jest ostatnie rozstrzygniecie NSA z 10 października 2018 r. w przedmiocie transkrypcji zagranicznego aktu stanu cywilnego - NSA uchylił wyrok sądu I instancji oraz negatywne decyzje organów i nakazał kierownikowi USC ponowne rozpatrzenie sprawy, wskazując, iż najważniejsze jest kierowanie się dobrem dziecka, ponieważ odmowa uznania aktu urodzenia szkodzi jego sytuacji prawnej i ogranicza w możliwości korzystania z praw i wolności obywatelskich, http://www.hfhr.pl/nsa-nie-mozna-odmowic-transkrypcji-zagranicznego-aktu-urodzenia-dziecka-rodziny-lgbt/ (dostęp: 10.10.2018 r.).

${ }^{32}$ W. Borysiak, Komentarz do art. 18 Konstytucji RP, w: Konstytucja RP. t. 1. Komentarz do art. 1-86, red. M. Safjan, L. Boska, Warszawa 2016, s. 487-490.

${ }^{33}$ Ibidem, s. 489. 
alnych, które wychowują dziecko z poprzedniego heteroseksualnego związku, jak i dziecko przysposobione ${ }^{34}$.

\section{Dobro dziecka w kontekście przysposobienia przez osoby LGBT*}

Można wyróżnić cztery rodzaje przysposobienia dziecka przez osoby homoseksualne:

- adopcję obcego dziecka przez samotną osobę,

- adopcję wspólną obcego dziecka,

- adopcję biologicznego dziecka partnera $\mathrm{z}$ poprzedniego związku,

- $\quad$ adopcję dziecka poczętego w wyniku sztucznego zapłodnienia przez partnera, który nie jest rodzicem biologicznym ${ }^{35}$.

Każde przysposobienie, niezależnie od tego, jakie podmioty będą go dokonywać, powinno być oparte przede wszystkim na realizacji przesłanki dobra dziecka. Podkreślenia wymaga, iż osoby homoseksualne powinny być oceniane w kwestii kompetencji rodzicielskich wedle analogicznych kryteriów jak osoby heteroseksualne wychowujące dzieci, a nie tylko $z$ punktu widzenia swojej orientacji seksualnej ${ }^{36}$. Dlatego też za nieuzasadnione uznać należy twierdzenia o potencjalnym zagrożeniu tego dobra w przypadku przysposobienia dziecka przez parę tej samej płci - każda osoba

${ }^{34}$ W sprawie Gas i Dubois przeciwko Francji (orzeczenie z 15 marca 2012 r., Izba (Sekcja V), skarga nr 25951/07) Trybunał wskazał, że co prawda art. 8 Konwencji nie gwarantuje ani prawa do założenia rodziny, ani prawa do adopcji, jednak konkretna sytuacja skarżących pozwalała uznać, że istniało między nimi „życie rodzinne” w rozumieniu art. 8, https://hudoc.echr.coe.int/eng\#\{,itemid”:[„001-109572”]\} (data dostępu: 28.07.2018 r.).

* Ze względu na ramy artykułu autorka omówiła jedynie zagadnienie adopcji i rodzicielstwa biologicznego osób LGBT. Osobnego omówienia wymagają pozostałe utrudnienia, z którymi stykają się osoby LGBT, w tym brak dostępu do metody in vitro.

${ }^{35}$ A. Śledzińska-Simon, Prawne możliwości adopcji przez pary jednoptciowe $w$ Europie. Perspektywa polska, w: Tęczowe rodziny $w$ Polsce. Prawo a rodziny lesbijskie i gejowskie, s. 81.

${ }^{36}$ M. Zima, Prawo osób homoseksualnych do życia rodzinnego, s. 37-41. 
przystępująca do postępowania adopcyjnego powinna być sprawdzana pod kątem tego, czy jej predyspozycje charakterologiczne, sytuacja osobista i majątkowa dadzą rękojmię właściwego zapewnienia rozwoju dziecka. Utworzenie więzi prawnej pomiędzy przysposobionym a przysposabiającym powinno być oparte na odpowiedniej ocenie kompetencji przysposabiającego do bycia rodzicem ${ }^{37}$. Takie twierdzenia uzasadnia brzmienie artykułu $114 \S 1$ k.r.o.

Jak podaje Jerzy F. Strzebińczyk, niebezpieczeństwo związane z przyznaniem prawa do wspólnej adopcji parom jednopłciowym nie jest związane $z$ obawą nienależytego wykonywania obowiązków wobec dziecka, ale $z$ możliwością jednostronnego wychowania dziecka. Jak argumentuje autor, związek kobiety i mężczyzny stanowi gwarancję zaspokojenia wszelkich aspektów rozwojowych dziecka. Na poparcie powyższego wskazuje „matczyną czułość” czy „ojcowską stanowczość”, których przejawy są warunkowane płcią rodzica $^{38}$. Tomasz Sokołowski wskazuje, iż konieczny jest wybór takiego środowiska rodzinnego dla dziecka, w którym możliwe będzie utworzenie więzi społecznych i emocjonalnych, przygotowujących je do dorosłego życia. Dzięki wychowaniu w stabilnych warunkach, w których dziecko ma możliwość poznania złożoności ról społecznych, będzie ono mogło w przyszłości założyć własną rodzinę opartą na podobnym wzorcu ${ }^{39}$. Odmienne stanowisko przyjmuje Anna Śledzińska-Simon, podając jako kryterium przysposobienia umiejętność pokochania dziecka i dbałość o jego dobro ${ }^{40}$. Orientacja homoseksualna, biseksualna czy heteroseksualna nie stanowi przesłanki, która a priori warunkuje zdolność przysposobienia dziecka ${ }^{41}$.

${ }^{37}$ A. Śledzińska-Simon, Adopcja przez osoby homoseksualne, w: Orientacja seksualna i tożsamość płciowa. Aspekty prawne i społeczne, red. R. Wieruszewski, M. Wyrzykowski, Warszawa 2009, s. 143-147.

38 J. F. Strzebińczyk, Prawo rodzinne, Warszawa 2016, s. 71-72.

39 T. Sokołowski, Dobro dziecka wobec rzekomego prawa do adopcji, w: Związki partnerskie - debata na temat projektowanych zmian prawnych, red. M. Andrzejewski, Toruń 2013, s. 106-115.

40 A. Śledzińska-Simon, Adopcja przez osoby homoseksualne, s. 145.

${ }^{41} \mathrm{~J}$. Gajda, Adopcja przez pary homoseksualne. Aspekty prawne, w: Zwiazki partnerskie - debata na temat projektowanych zmian prawnych, red. M. Andrzejewski, Torun 2013, s. 120-121. 
Kodeks rodzinny i opiekuńczy przewiduje dwa typy przysposobienia $z$ punktu widzenia kryterium osobowego - przez małżonków oraz przez osobę samotną. W literaturze dominuje pogląd, zgodnie z którym wspólna adopcja przez małżonków stanowi rozwiązanie najbardziej odpowiadające realizacji dobra dziecka, gdyż daje mu możliwość dorastania w pełnej rodzinie. Adopcja singularna jest oparta na założeniu, że również jedna osoba jest w stanie zapewnić dziecku odpowiednie warunki rozwoju i wychowania. Pod pojęciem „normalnych” czy „optymalnych” warunków rozwoju znaczna część doktryny prawa rodzinnego rozumie wychowywanie dziecka w rodzinie opartej na związku małżeńskim kobiety i mężczyzny. Warto jednak podkreślić abstrakcyjny charakter pojęcia „dobro dziecka” nie można go określić konkretnie i jednoznacznie w odniesieniu do każdej sytuacji faktycznej, tak jak czyni się w to w odniesieniu do par jednopłciowych. Pojęcie dobra dziecka należy do kategorii pojęć nieostrych, gdyż samo w sobie nie ma precyzyjnego znaczenia, odniesienia ${ }^{42}$.

Formalnie nie jest zabroniona adopcja dziecka przez osobę nieheteronormatywną, jednak szanse na jej dokonanie w obecnym stanie prawnym przez osobę samotną, nawet heteroseksualną, są bardzo niewielkie ${ }^{43}$. Celem adopcji jest stworzenie dziecku optymalnych warunków rozwoju. $Z$ założenia mają to być warunki lepsze niż dom dziecka czy rodzina zastępcza. Stosunek przysposobienia ma zatem wykreować zastępcze środowisko rodzinne, które powinno być jak najbardziej zbliżone do standardowego środowiska wychowania dziecka w rodzinie pełnej ${ }^{44}$.

${ }^{42}$ H. Ciepła, B. Czech, Kodeks rodzinny i opiekuńczy z komentarzem, Warszawa 2002, s. 302. Specyfika nadawania znaczenia terminom nieostrym i problemy z tym związane są dobrze rozpoznane w literaturze teoretycznoprawnej. Tak: Z. Tobor, W poszukiwaniu intencji prawodawcy, Warszawa 2013, s. 189-209, A. Bielska-Brodziak, Śladami prawodawcy faktycznego. Materiały legislacyjne jako narzędzie wykładni prawa Warszawa 2017, s. 394-402, T. Gizbert-Studnicki, Vagueness, Open Texture and Law, „Archivum Iuridicum Cracoviense" 1983/XVI, s. 15 i n.

${ }^{43}$ A. Śledzińska-Simon Prawne możliwości adopcji przez pary jednopłciowe $w$ Europie, s. 85.

${ }^{44}$ J. F. Strzebińczyk Prawo rodzinne, s. 331. 
Ocena, czy określona osoba lub osoby są zdolne sprawować odpowiednio władzę rodzicielską, musi być oparta na starannym bilansie obejmującym wszelkie konfiguracje elementów stanu faktycznego dotyczącego zarówno dziecka, jak i przysposabiających (np. stanu zdrowia, stopnia rozwoju, zainteresowań, doświadczenia życiowego, charakteru, sytuacji materialnej), a następnie uzasadnieniu, dlaczego określona konfiguracja jest dla dziecka najlepsza. Dlatego też nie można $z$ góry założyć, iż orientacja seksualna rodzica per se stanowi zagrożenie dla dziecka, tak samo jak rodzina oparta na związku kobiety i mężczyzny nie może być uznana za jedynego gwaranta odpowiedniego kształtowania postaw życiowych dziecka i środowiska wychowawczego. Zatem to nie orientacja seksualna rodzica, a dobro dziecka powinno stanowić naczelne kryterium ocen w zakresie decyzji jego dotyczących ${ }^{45}$.

Ocena powinna być dokonywana na podstawie tych samych kryteriów zarówno wobec osób hetero-, jak i wobec osób homoseksualnych. Należy podkreślić, iż adopcja przez osoby homoseksualne nie dotyczy tylko sytuacji przysposobienia dziecka cudzego, ale najczęściej będzie dotyczyła sytuacji, w której partner nie może przysposobić biologicznego dziecka drugiego partnera. Sytuację dodatkowo komplikuje brak możliwości sformalizowania związku pomiędzy partnerami. To powoduje powstanie nierównych praw rodzicielskich, a także wpływa niekorzystnie na sytuację dziecka,

45 M. Zima, Prawo osób homoseksualnych do życia rodzinnego, s. 49-50. W tym kontekście warto przytoczyć sygnalizacyjnie sprawę E.B. przeciwko Francji - wyrok ETPC z dnia 22 stycznia 2008 r., skarga nr 43546/02, w którym Trybunał wskazał na naruszenie art. 14 Konwencji (zakaz dyskryminacji) w zw. $\mathrm{z}$ art. 8 Konwencji w związku $\mathrm{z}$ odmową adopcji dziecka przez osobę homoseksualną, skoro bowiem prawo francuskie dopuszcza adopcję przez jedną osobę, to nie można różnicować tych osób i odmawiać adopcji z racji orientacji homoseksualnej. Jak wskazał Trybunał, skarżąca przedstawiała niewątpliwe osobiste kwalifikacje i zdolność do wychowania dzieci będące z pewnością w najlepszym interesie dziecka. Oddalając wniosek o zgodę na adopcję, władze dokonały zróżnicowania w oparciu o względy dotyczące orientacji seksualnej niedające się zaakceptować na podstawie konwencji (M.A. Nowicki, E.B. przeciwko Francji - wyrok ETPC z dnia 22 stycznia 2008 r., skarga nr 43546/02, w: M.A. Nowicki, Europejski Trybunał Praw Człowieka. Wybór orzeczeń 2008, Warszawa 2009, s. 159). 
ponieważ rodzic społeczny, z którym jest ono związane więzami emocjonalnej bliskości, może być wyłączony $z$ decydowania o kwestiach zdrowotnych czy edukacyjnych. Ponadto - co wydaje się wyjątkowo okrutne - w sytuacji śmierci partnera rodzic społeczny nie ma żadnych uprawnień względem dziecka i w rezultacie może dojść do utraty obojga rodziców przez dziecko ${ }^{46}$. Stąd uzasadnione jest twierdzenie, iż obecny stan prawny nie zabezpiecza w pełni realizacji zasady dobra dziecka - czyni to w pełnym zakresie jedynie $\mathrm{w}$ stosunku do dzieci wychowywanych w tradycyjnie pojmowanej rodzinie, pozostawiając na marginesie dzieci wychowywane przez pary jednopłciowe.

\section{Podsumowanie}

Współczesne badania potwierdzają, że orientacja seksualna rodziców nie ma wpływu na rozwój psychiczny dziecka. Tak samo jak różnorodne jest społeczeństwo, różnorodne są konfiguracje życia rodzinnego. Odmienność od zastanego tradycyjnie kształtu tych form nie musi świadczyć o ich patologizacji. Należałoby więc zastanowić się nad tym, czy w ogóle uzasadnione jest wyróżnianie kategorii rodziców hetero- i homoseksualnych. Wyodrębnianie takich kategorii samo w sobie ma kontekst dyskryminacyjny, powoduje wszak, że orientacja seksualna rodzica staje się najważniejszym kryterium oceny jego kompetencji rodzicielskich ${ }^{47}$. Tworzenie takich kategorii, winno być zjawiskiem przejściowym, do czasu powstania nowych pojęć albo adaptacji zastanych pojęć do nowych form rodzicielstwa. Podkreślenia wymaga również to, że społeczna i polityczna stygmatyzacja osób nieheteronormatywnych może negatywnie odbić się na zdrowiu psychicznym i fizycznym dzieci wychowywanych przez te osoby. Zatem to niska tolerancja

${ }^{46}$ P. Tomalski, Pary jednopłciowe, zakładanie rodzin, rodzicielstwo, rozwój dzieci, w: Tęczowe rodziny $w$ Polsce. Prawo a rodziny lesbijskie i gejowskie, red. M. Zima, Warszawa 2010, s. 30-31.

47 J. Stacey, T.H. Biblarz, (How) Does the Sexual Orientation of Parents Matter? “American Sociological Review” 2001, Vol. 66, No. 2, pp. 176-177. 
społeczeństwa dla związków jednopłciowych i ich rodzicielstwa może stanowić istotne zagrożenie dla dobra dziecka. Ugruntowany pogląd o naturalnej predyspozycji związków heteroseksualnych jako jedynej wspólnoty, w ramach której możliwy jest prawidłowy rozwój dziecka, jest błędny. Przetwarzany w dyskursie argument Z „zagrożenia dobra dziecka” w razie otwarcia możliwości adopcji dla par jednopłciowych podawany jest jak dogmat, który nie wymaga uzasadnienia, a którego głównym zadaniem jest manipulowanie społecznymi lękami i emocjami wynikającymi $z$ niewiedzy na temat życia rodzinnego osób LGBT.

Współczesne przemiany życia rodzinnego nie wiążą się z rozkładem tradycyjnego modelu rodziny czy „końcem rodziny”, a z jego przekształceniem, przybraniem nowej formy ${ }^{48}$. Współczesna rodzina to przede wszystkim wspólnota więzi faktycznych, niekoniecznie połączona więzami krwi. Jak podkreśla Andrew Sullivan, uznanie praw osób LGBT do zawarcia sformalizowanego związku i rodziny leży w interesie społeczeństwa, gdyż dostarcza ona emocjonalnej stabilności, bezpieczeństwa ekonomicznego oraz wiąże się z powstaniem wzajemnej odpowiedzialności, a co za tym idzie - nie tylko nie stanowi odrzucenia czy zaprzeczenia wartości rodzinnych, ale jest ich dopełnieniem i wzmocnieniem ${ }^{49}$. Na przestrzeni ostatnich 20 lat za granicą wyraźnie nasilił się proces instytucjonalizacji związków jednopłciowych ${ }^{50}$. W Polsce, pomimo iż debata nad sta-

${ }^{48}$ K. Slany, Dywersyfikacja form życia rodzinnego we współczesnym świecie. Przykład związków homoseksualnych, w: Homoseksualizm $w$ perspektywie interdyscyplinarnej, red. K. Slany, B. Kowalska, M. Śmietana, Kraków 2008, s. 22-23.

49 A. Sullivan, Here Comes the Groom, "The New Republic" 1989, nr 28, https://newrepublic.com/article/79054/here-comes-the-groom (dostęp: 19.06. 2018 r.).

${ }^{50} \mathrm{~W}$ zakresie prawnej regulacji związków jednopłciowych w Europie można zaobserwować dużą różnorodność form instytucjonalizacji - od związków o charakterze umowy cywilnoprawnej po małżeństwa jednopłciowe. Ponadto w kilku państwach istnieje możliwość zawarcia przez pary jednopłciowe małżeństwa albo zarejestrowanego partnerstwa, w zależności od wyboru zainteresowanych. W 16 państwach europejskich instytucja małżeństwa została otwarta dla osób tej samej płci (Austria, Belgia, Dania, Francja, Finlandia, Islandia, Irlandia, 
tusem prawnym związków homoseksualnych trwa od 15 lat w różnym natężeniu, nie wprowadzono żadnych rozwiązań regulujących pożycie tych par. Biorąc pod uwagę względy natury zarówno konstytucyjnej, jak i cywilnoprawnej polskiego porządku prawnego nie ma przeciwskazań (wręcz przeciwnie) do wprowadzenia instytucji zarejestrowanego związku partnerskiego dla par jednopłciowych opartej na normatywnym modelu małżeństwa ${ }^{51}$.

Warto wskazać, że już podczas prac w Komisji Konstytucyjnej Zgromadzenia Narodowego kilkakrotnie podawano argument o „zagrożeniu dobra dziecka” w razie dopuszczenia innej formuły definicyjnej małżeństwa niż taka, która obecnie jest zawarta w art. 18 Konstytucji RP. Jedną z konsekwencji instytucjonalizacji związków jednopłciowych jest uznanie rodzicielstwa takich związków. Posłanka Maria Kurnatowska wskazywała, przykładowo że „trudno jest sobie wyobrazić macierzyństwo w przypadku małżeństwa dwóch mężczyzn czy dwóch kobiet”. Pogląd ten potwierdził poseł Piotr Andrzejewski: „Moja wyobraźnia tego nie obejmuje. Rozumiem, że poseł Kurnatowska ma na myśli macierzyństwo naturalne. Ja też tak to rozumiem. W grę wchodzi jednak również macierzyństwo prawne, na przykład w przypadku związku dwóch homoseksualistów. W związku takim nie wiadomo, kto pełni rolę matki, a kto rolę ojca, dlatego m.in. taką sytuację uważam za patologiczną”. Powstaje wobec tego pytanie, czy intencja ustawodawcy ukształtowana

Luksemburg, Holandia, Norwegia, Portugalia, Hiszpania, Szwecja, Wielka Brytania). W 16 państwach europejskich została wprowadzona instytucja zarejestrowanego partnerstwa, o zbliżonym statusie do małżeństwa (Andora, Austria, Chorwacja, Cypr, Finlandia, Niemcy, Grecja, Węgry, Irlandia, Lichtenstein, Luksemburg, Malta, Holandia, Szwajcaria, Wielka Brytania). W 6 państwach europejskich występuje forma związku partnerskiego oparta na modelu kontraktowym (Andora, Belgia, Czechy, Estonia, Francja, Słowenia). W sporej części państw europejskich (19) nadal nie została wprowadzona żadna instytucjonalna możliwości sformalizowania związku jednopłciowego (Albania, Armenia, Azerbejdżan, Białoruś, Bośnia i Hercegowina, Bułgaria, Kosowo, Litwa, Macedonia, Mołdawia, Monako, Czarnogóra, Rumunia, Rosja, Polska, Serbia, Słowacja, Turcja, Ukraina).

${ }^{51}$ J. Pawliczak, Zarejestrowany związek partnerski a małżeństwo, Warszawa 2014, s. 361-370. 
w 1995 r. na podstawie stereotypowych i uznaniowych przesłanek może pozostać aktualna na całe przyszłe lata? ${ }^{52}$

Reasumując, zgodnie $z$ Konwencją o prawach dziecka ${ }^{53}$ zadaniem państw, będących stronami tej umowy, jest jak najlepsze zabezpieczenie interesów dziecka, bez dyskryminacji. Ochrona dziecka jest gwarantowana niezależnie od tego, kim są jego rodzice i jaki jest ich status prawny. Dobro dziecka jako wartość nadrzędna powinna odrywać się od płci, orientacji seksualnej rodzica i nie może stanowić naczelnego kryterium jego oceny. Stabilny status prawny rodziców jest gwarancją stabilnego statusu prawnego dziecka, jest to bowiem sytuacja ściśle powiązana. Wobec tego z jednej strony konieczne jest oderwanie się od stereotypowych przekonań na temat rodzicielstwa osób nieheteronormatywnych, tak aby oceniać ich w kategoriach kompetencji rodzicielskich, a nie ich orientacji seksualnej, a $z$ drugiej strony ustawodawca musi dostrzec, iż faktem społecznym jest to, że w ramach związków jednopłciowych wychowywane są dzieci, które podobnie jak każde inne potrzebują stabilnej i pewnej ochrony prawnej.

\section{STRESZCZENIE}

Kilka uwag na tle statusu prawnego rodzin $z$ wyboru

Rodziny $\mathrm{z}$ wyboru funkcjonują $\mathrm{w}$ sferze faktów, nie prawa - ustawodawca pozostaje obojętny na fakt ich obecności w rzeczywistości społecznej. Obojętność ustawodawcy przekłada się na realny status rodzin z wyboru status samych związków jednopłciowych i wychowywanych przez nich dzieci. W debacie na temat instytucjonalizacji związków jednopłciowych często podnosi się argument „zagrożenia dobra dziecka” w razie umożliwienia sformalizowania związków jednopłciowych w prawie polskim.

${ }^{52}$ Komisja Konstytucyjna Zgromadzenia Narodowego, Biuletyn XVII, Wydawnictwo Sejmowe, Warszawa 1995, s. 33, https://bs.sejm.gov.pl/exlibris/ aleph/a22_1/apache_media/DDNEBMFGB28MFMXQPE1X6EJF2FD3E6.pdf (dostęp: 14.05.2018 r.).

${ }^{53}$ Konwencja o prawach dziecka przyjęta przez Zgromadzenie Ogólne Narodów Zjednoczonych dnia 20 listopada 1989 r. (Dz.U. z 1991 r. Nr 120, poz. 526); w szczególności należy zwrócić uwagę na art. 2 Konwencji. 
Autorka artykułu analizuje wybrane zagadnienia statusu prawnego tzw. rodzin $z$ wyboru, w tym pojęcie „dobra dziecka” w kontekście rodzicielstwa związków jednopłciowych.

Słowa kluczowe: rodziny z wyboru; dobro dziecka; adopcja; instytucjonalizacja związków jednopłciowych

\section{SUMMARY}

A few comments about the legal status of families of choice

The families of choice function in the real life, not law - the legislator remains indifferent to the fact of their functioning in the social reality. The indifference of the legislator translates into the real status of "families of choice" - the status of same-sex couples and the children raised by them. In the debate on the institutionalization of same-sex relationships, the argument from the "threat to the best interest of the child" is often raised in the case of the possibility of institutionalization same-sex relationships in Polish law. The author of the article analyzes selected issues of the legal status of families of choice, in particular the concept of "best interest of the child" in the context of the parenting of same-sex relationships.

Keywords: families of choice; best interest of the child; adoption; institutionalization of same-sex relationships

\section{BIBLIOGRAFIA}

Borysiak W., Komentarz do art. 18 Konstytucji RP, w: Konstytucja RP. t. 1. Komentarz do art. 1-86, red. M. Safjan, L. Bosek, Warszawa 2016.

Ciepła H., Czech B. Kodeks rodzinny i opiekuńczy z komentarzem, Warszawa 2002.

Gajda J., Adopcja przez pary homoseksualne. Aspekty prawne, w: Związki partnerskie - debata na temat projektowanych zmian prawnych, red. M. Andrzejewski, Torun 2013.

Łączkowska M., Związki osób tej samej ptci w świetle prawa polskiego, w: Prawo wobec wyznawań współczesności, t. III, red. P. Wiliński, O. Krajniak, B. Guzik, Poznań 2006.

Majka-Rostek D., Lesbijki, geje i ich dzieci - różnorodność form rodzinnych, „InterAlia” 2013, nr 8. 
Majka-Rostek D., Macierzyństwo lesbijek - wybrane konteksty społeczne, „Studia Socjologiczne” 2014, nr 4.

Mizielińska J., Stasińska A., Prywatne jest polityczne: strategie emancypacyjne rodzin $z$ wyboru $w$ Polsce. Studium wybranych przypadków, „Studia Socjologiczne” 2014, nr 4.

Mizielińska J., Abramowicz M., Stasińska A., Rodziny z wyboru w Polsce. Życie rodzinne osób nieheteroseksualnych, Warszawa 2014, http:// rodzinyzwyboru.pl/wp-content/uploads/2014/10/Raport_Rodziny-z -wyboru-w-Polsce.-\%C5\%BBycie-rodzinne-os\%C3\%B3b-nieheteroseksualnych.pdf (dostęp: 20.04.2018 r.).

Mizielińska J., Stasińska A., Rodzina z wyboru, hasło w: Encyklopedia gender. Płeć kulturowa, red. K. Nadana, G. Latos, IBL PAN (w przygotowaniu), s. 1, http://rodzinyzwyboru.pl/wp-content/uploads/2013/07/ Joanna-Mizielińska_Agata-Stasińska_hasło-Rodziny-z-wyboru_Encyklopedia-Gender.-Płeć-kulturowa_red.-K.-Nadana-G.-Latos_IBL-PAN-pdf. pdf (dostęp: 20.07.2018).

Nowicki M.A., E.B. przeciwko Francji - wyrok ETPC z dnia 22 stycznia 2008 r., skarga nr 43546/02, w: M.A. Nowicki, Europejski Trybunat Praw Człowieka. Wybór orzeczeń 2008, Warszawa 2009.

Pawliczak J., Zarejestrowany związek partnerski a małżeństwo, Warszawa 2014.

Pilch M., Związki quasi-małżeńskie $w$ polskim prawie prywatnym międzynarodowym (po nowelizacji k.k.), „Państwo i Prawo” 2011, nr 2.

Slany K., Alternatywne formy życia mał̇̇eńsko-rodzinnego $w$ ponowoczesnym świecie, Kraków 2002.

Slany K., Dywersyfikacja form życia rodzinnego we wspótczesnym świecie. Przykład związów homoseksualnych, w: Homoseksualizm w perspektywie interdyscyplinarnej, red. K. Slany, B. Kowalska i M. Śmietana, Kraków 2008.

Smyczyński T., Małżeństwo - konkubinat - związek partnerski, w: Związki partnerskie - debata na temat projektowanych zmian prawnych, red. M. Andrzejewski, Toruń 2013.

Smyczyński T., w: Prawo rodzinne i opiekuńcze. System prawa prywatnego, t. 11, red. T. Smyczyński, Warszawa 2014.

Sokołowski T., Dobro dziecka wobec rzekomego prawa do adopcji, w: Związki partnerskie - debata na temat projektowanych zmian prawnych, red. M. Andrzejewski, Toruń 2013.

Stacey J., Biblarz T.J., (How) Does the Sexual Orientation of Parents Matter?, "American Sociological Review" 2001, Vol. 66, No. 2.

Strzebińczyk J.F., Prawo rodzinne, Warszawa 2016.

Sullivan A., Here Comes the Groom, „The New Republic” 1989, nr 28, https:// 
newrepublic.com/article/79054/here-comes-the-groom (dostęp: 19.06. 2018 r.).

Szlendak T., Socjologia rodziny. Ewolucja, historia, zróżnicowanie, Warszawa 2012.

Śledzińska-Simon A., Adopcja przez osoby homoseksualne, w: Orientacja seksualna i tożsamość ptciowa. Aspekty prawne i społeczne, red. R. Wieruszewski, M. Wyrzykowski, Warszawa 2009.

Śledzińska-Simon A., Prawne możliwości adopcji przez pary jednopłciowe $w$ Europie. Perspektywa polska, w: Tęczowe rodziny $w$ Polsce. Prawo a rodziny lesbijskie i gejowskie, red. M. Zima, Warszawa 2010.

Tomalski P., Nietypowe rodziny. O parach lesbijek i gejów oraz ich dzieciach z perspektywy teorii przywiazania, Warszawa 2007.

Tomalski P., Pary jednopłciowe, zakładanie rodzin, rodzicielstwo, rozwój dzieci, w: Tęczowe rodziny $w$ Polsce. Prawo a rodziny lesbijskie i gejowskie, red. M. Zima, Warszawa 2010.

Ukleja M. Rodziny z wyboru. Homoseksualny związek jako wspótczesna alternatywa rodziny - Analiza zjawiska, „Acta Universitatis Lodziensis. Folia Sociologica” 2014, nr 51.

Zachariasiewicz M.A., Nowa ustawa o prawie prywatnym międzynarodowym a małżeństwa i zwiazki osób tej samej ptci, „Problemy Prawa Prywatnego Międzynarodowego” 2012, t. 11.

Zima M., Prawo osób homoseksualnych do życia rodzinnego - prawo do wychowania własnych dzieci, w: Tęczowe rodziny $w$ Polsce. Prawo a rodziny lesbijskie i gejowskie, red. M. Zima, Warszawa 2010. 